\title{
Multilevel governance in trouble: the implementation of asylum seekers' reception in Italy as a battleground
}

\author{
Francesca Campomori ${ }^{*}$ and Maurizio Ambrosini ${ }^{2}$
}

\author{
* Correspondence: francesca. \\ campomori@unive.it \\ This article belongs to a special \\ issue (contact person Caroline \\ Oliver Caroline.Oliver@roehampton. \\ ac.uk) \\ ${ }^{1}$ University of Venice, Malcanton \\ Marcorà Dorsoduro 3484/A 30123, \\ Venezia, Italy \\ Full list of author information is \\ available at the end of the article
}

\begin{abstract}
The reception of asylum seekers in Italy has become an increasingly contentious issue: many actors, public and private, are involved at various levels of government, and cooperative behaviour cannot be taken for granted. The multi-level governance approach sheds light on the possible patterns in vertical relations, while it does not effectively explore the horizontal relations, which are however crucial, especially at the local level. Moreover, we argue that the definition of multilevel governance as negotiated order among public and non-public actors is too rigid and normative. Local policies of reception are instead a playing field where different actors come together with different interests, values and frames. This paper discusses the implementation of asylum seekers' reception in Italy, looking at both the multilevel and the horizontal dynamics, and it uses the concept of 'battleground' in order better to grasp the complexities of the interaction between actors. The article discloses conflicting and competing frames between different tiers of governance, since municipalities try to resist government imposition related to asylum seekers' reception in their areas. As for the horizontal dynamics, this paper argues that four possible patterns emerge in the relation between state and state actors: a) closure vs. civil society activism; b) tolerance; c) institutional activism vs. anti-immigrant mobilizations; d) cooperation. Overall, the paper aims at addressing the limits of the MLG approach by means of a conceptual tool (the "battleground") which yields a more vivid understanding of implementation dynamics.
\end{abstract}

Keywords: Multilevel-governance, Battleground, Asylum seekers and refugees

\section{Introduction}

At the end of the 1990s the interplay and intertwining between different levels of political regulation of migration started to be increasingly studied in order to provide better understanding of the migration policy process. At the same time, the shifting of responsibility to non-state actors also became an issue. Two main approaches emerged in this field of studies, i.e. the venue-shopping and the multilevel governance approaches. The former (Guiraudon 2000; Guiraudon and Lahav 2000; Lahav and Guiraudon 2006) deals exclusively with immigration control and argues that nation-states' responses consist of devolution of decision making upward to intergovernmental fora,

(c) The Author(s). 2020 Open Access This article is licensed under a Creative Commons Attribution 4.0 International License, which permits use, sharing, adaptation, distribution and reproduction in any medium or format, as long as you give appropriate credit to the original author(s) and the source, provide a link to the Creative Commons licence, and indicate if changes were made. The images or other third party material in this article are included in the article's Creative Commons licence, unless indicated otherwise in a credit line to the material. If material is not included in the article's Creative Commons licence and your intended use is not permitted by statutory regulation or exceeds the permitted use, you will need to obtain permission directly from the copyright holder. To view a copy of this licence, visit http://creativecommons.org/licenses/by/4.0/. 
downward to local authorities, and outward to non-state actors, such as private companies, employers and private security agencies (Guiraudon and Lahav 2000, 164). This framework has been used to claim the move of domestic policy-makers to EU policy venues (particularly in order to avoid judicial constraints and the opposition of other political actors or pro-immigrant groups) and the co-opting of private actors in the performance of the migration control 'function' (Lahav and Guiraudon 2006, 212).

The multilevel governance [MLG] approach instead looks mainly at integration policies (Hepburn and Zapata-Barrero 2014; Scholten and Pennix 2016; Scholten et al. 2018; Spencer 2018) and it gained momentum among migration scholars soon after the "local turn" in the research on immigrant integration policies (Caponio and Borkert 2010). Born as an alternative approach to intergovernmentalism and functionalist theories of EU integration (Schmitter 2004), MLG turned to a wider conceptual space claiming an enhanced understanding of the policymaking process. In the current scenario the centralised nature of the nation state has been challenged by almost simultaneous processes of supranationalisation and devolution to sub-state units (vertical dimension) and by the growing importance of non-governmental actors (horizontal dimension). The intersection between vertical and horizontal dimensions should be the distinctive feature of this approach (Bache and Flinders, 2004), which entails an exploration of both vertical and horizontal dynamics of migration policymaking in multilevel settings. To date, however, most studies have explored mainly the vertical or multilevel aspect of MLG, i.e. the involvement of different levels of government and their relations (for a review see Caponio and Jones-Correa 2017), while the horizontal dimension, as well as the relations between vertical and horizontal space, are much less developed. MLG perspective displays more analytical power in grasping the intergovernmental dimension than the horizontal public/private governance. We argue that one of the main reasons for this lies in the definition itself of multilevel governance as a structure of relations which involves some forms of coordinated actions and where the frames of migrant integration are similar or at least congruent between levels (Scholten 2013). As we will explain extensively in the next sections in relation to the Italian case, this definition hardly fits with horizontal dynamics at the local level, as the interplay between state and non-state actors is often far from resembling a coordinated action within a similar frame. Put otherwise, MLG emphasises cooperation and coordination among actors, but the actual governance of immigration is also the product of conflicting processes, e.g. fights, protests, difficult interactions (Dabrowski et al. 2014). Various actors, such as pro and anti-immigrant organizations/groups and the immigrant organization themselves, play an active role in these processes: this interplay is crucial in order to understand the outcome of the policy process. Actors and networks should be systematically integrated into the MLG approach (Taylor et al. 2013). This gap has been partially coped by the literature on (new) urban governance (da Cruz et al. 2019, for a review), which nevertheless does not systematically consider the multilevel interaction. Another shortcoming of the MLG approach is that it has been usually applied to regular migration and only rarely to asylum-seeker reception (recent exceptions are Spencer 2018 and Panizzon and Van Riemsdijk 2018).

This article discusses the implementation of asylum seekers' reception in Italy after the so-called "refugee crisis". Drawing on the conceptual tools of MLG in analysing the policy process, we attempt to address its gaps and discuss a possible way out. Our 
research question is: how and to what extent MLG perspective is useful in explaining implementation dynamics in refugee policies? In relation to this question the article aims at achieving two main goals: (i) explaining that a twofold analysis -where both the multilevel and the horizontal governance dynamics are investigated - yields a more comprehensive understanding of the complexity of asylum-seeker reception; (ii) offering a complementary perspective for analysing the horizontal interactions. As regards the second goal, the article takes advantage of the concept of "battleground" introduced by Ambrosini (2018): it helps to deepen the multi-actor, conflictual and plural local dynamics, since these dynamics do not necessarily stem from a negotiated order among interdependent actors (Alcantara and Nelles 2014). Asylum-seeker policy can be framed as a battleground upon which different actors engage with their own interests, values and frames. We believe that this concept displays a significant analytical potential because it effectively discloses how the migration process is managed not only by national and local political authorities and legislations, and not only by NGOs working in collaboration with state actors: it is also an outcome of the interplay among other actors, such as migrants themselves, pro-immigrant actors and social movements (e.g. No Borders) and xenophobic movements (Fontanari and Ambrosini 2018; Castelli Gattinara 2017; Pettrachin 2020; see also Lahav and Guiraudon 2006 and their concept of MultiLevel Playing Field).

The paper proceeds as follows. In the next section we provide an overview of the impact of the "refugee crisis" in Italy. Section 3 analyses the (difficult) relations between national and local level, i.e. the vertical patterns in Italian reception policies. We build on Scholten's typology (2013) concerning the possible patterns that occur in the interplay among the tiers, illustrating its limitations in explaining asylum-seekers reception in Italy. In section 4 we move to the horizontal dimension and analyse the governance patterns at the local level. To this end, we first map the main categories of actors who confront each other on the battleground, disclosing their different frames and values as well as their specific actions. Then, we analyse the dynamics of the battleground, highlighting both the exclusionary policies and the innovative and inclusive practices, often implemented by voluntary or third-sector organizations. Finally, we present a typology which illustrates the different configurations of state and non-state actors' relations. The conclusions summarise the main findings and suggest directions for future research.

\section{The "refugee crisis" in Italy: an appraisal}

Until recent years the whole issue regarding forced migration was almost entirely ignored by public policies ${ }^{1}$ because Italy did not perceive itself as an asylum-seeker hosting country; indeed, until 2011 asylum applicants were relatively few in number if compared with those in north-western European countries. Italy has long kept itself on the margins of asylum seekers' routes: for years, the Italian authorities unofficially allowed them to pass through the country, silently supporting their journey to other countries where they had relatives and friends and where national policies were more receptive (Ambrosini 2018, 81) ${ }^{2}$. It is thus not surprising that in Italy an organic law

${ }^{1}$ In 2002 Italian Government formally established a national system for refugees' reception (System for Protection of Asylum Seekers and refugees [SPRAR]), but until 2014 it was largely unfunded. 
on the reception of refugees does not exist, although since 1990 Italian Parliament approved many laws on this topic as part of the process of harmonization of EU countries' legislation on asylum.

The so-called 'North Africa Emergency' (Emergenza Nord Africa) in 2011, when more than 62,000 boat people from African countries arrived in Italy by sea, dramatically revealed the inconsistency of the Italian reception system: an emergency approach predominated (Civil Protection/Protezione Civile managed the "emergency") ${ }^{3}$, while a more comprehensive vision of what was happening did not seem to emerge.

The 170,000 asylum-seekers who disembarked on Italian shores in 2014 led to an Agreement between State, Regions and Local Authorities (Accordo conferenza Unificata, 10 July 2014) ${ }^{4}$ and to the approval of a law (Legislative decree no.142/2015) ${ }^{5}$ which tried (not always successfully) to supersede the emergency logic hitherto dominant. The two main issues were: (i) achieving, through a quota system, a homogeneous distribution of asylum-seekers in all the country's regions (until 2014 there were huge imbalances and $70 \%$ of asylum-seekers were hosted in three southern regions, i.e. Sicily, Apulia and Calabria); and (ii) achieving effective institutional cooperation among different levels of government (to this end ad hoc bargaining tables were foreseen). The second point includes the design of a reception system where the national level assumes the role of coordinator. This system consists of three phases: rescue and first aid, including identification of migrants; first level of reception in centres led by the Ministry of Interior (CARA, Reception Centre for Asylum Seekers or CDA, Reception Centre); second level of reception in SPRAR (Protection System for Asylum Seekers and Refugees), which includes language course, psychological and legal support, traineeship and an individualised project of integration. According to the law no.142/2015 SPRAR was intended to become the mainstream for all asylum-seekers. Local authorities play a crucial role in the institution of a SPRAR project because they are requested on a voluntary basis to launch the reception project in collaboration with NGOs and associations. The Home Affairs Ministry encouraged the implementation of SPRAR, described "as a structured form to achieve a widespread reception, overcoming extraordinary solutions, and taking into account, at the same time, variegated local situations, avoiding imbalances and non-homogeneous distributions" (Ambrosini 2018, 116-117), but the resistance of local authorities led to a lack of reception facilities, and the government responded by creating a parallel system based on the Centres of Extraordinary Reception [CAS]: again an emergency response to a recurrent structural issue. In this case, the national authorities by-passed local governments, giving to private actors (mainly NGOs, but not only: also hotel owners and other private employers) the task of establishing and managing reception facilities of various kinds. Local governments in

\footnotetext{
${ }^{2}$ In 2015 the introduction of the Hotspot approach (within the European Agenda on migration) made much more difficult for Italian Authorities to put a blind eye on transit.

${ }^{3}$ Following an agreement signed in April 2011 by the Government, the Regional Authorities, the Association of Italian Municipalities (ANCI) and the Union of Italian Provinces (UPI), the system of the Civil Protection was charged with the implementation of an extraordinary reception plan with the purpose of distributing migrants throughout Italy, according to the reception capacity of each region. After two years this plan ended and the centres were closed.

${ }^{4}$ http://www.prefettura.it/FILES/AllegatiPag/1247/Accordo\%20Conferenza\%20Unificata.pdf

${ }^{5}$ Most Italian legislation on asylum originates from transposition of EU directives. Legislative decree no.142/ 2015 is not an exception, since it implements directive 2013/32 and 2013/33.
} 
principle cannot block the settlement of CAS on their territory, even if in some cases, through protests or legal cavils, they managed to do it.

The actual implementation of the overall reception system revealed some crucial deficits due to conflicts and lack of cooperation between national and local tiers. The implementation phase also revealed the activism of non-state actors, who are able to change the expected policy outcomes. Even more important is their role in the assistance of (recognised) refugees who do not receive any support by public policies ${ }^{6}$ and of rejected asylum seekers.

The scenario has been further changed with the approval, on 1 December 2018, of law no.132/2018 by the populist government led by Northern League and 5 Stars Movement: this law modified the reception system in a restrictive direction. According to this law, CASs should deliver to asylum seekers just "bath, bed and bread", while the other services are no longer funded. Even before the new rules CASs displayed quality standards significantly lower than SPRARs, but the law further reduces them: for instance, it foresees a cut in the number of cultural mediators and social workers and it does not funds anymore Italian courses. In addition to this, SPRAR -which has been renamed SIPROIMI (Protection system for people holding international protection and unaccompanied minors)- is no longer accessible for asylum-seekers and migrants entitled with humanitarian protection ${ }^{7}$. Finally, it has to be noticed that, after the agreement signed in February 2017 between Libya and Italy, the number of people landed in Italy has hugely decreased (from 119,247 asylum-seeker in 2017 to 23,400 in 2018 and 11.439 in 2019) ${ }^{8}$.

\section{The competing frames in vertical interactions between national and sub- national levels}

As said above, the agreement signed in 2014 within the State-Regions conference, and the decree no.142/2015, committed national, regional and local level to cooperating on refugees' reception.

However, in practice, things went differently, and the level of cooperation has been low. Although the national SPRAR should have become the mainstream in the reception system, few asylum seekers and refugees have been hosting in it because only a tiny minority of local authorities agreed to manage a SPRAR project. In order to convince municipalities to host the SPRAR's network government gave also an incentive to them: municipalities who host a SPRAR have been exempted from additional reception centres (.i.e. CAS).

A SPRAR project in fact starts only if a municipality applies to Government's call: the participation is voluntary. In January 2019, around 1,800 out of almost 8,000

\footnotetext{
${ }^{6}$ Also refugees who have obtained legal entitlement to international protection, in fact, often do not receive any assistance: a few days after their recognition as refugees, they have to leave the reception facilities in which they were hosted and in most cases they find themselves on the streets.

${ }^{7}$ The law no.132/2018 abolishes the permit for humanitarian reasons, introduced in the Italian legal system in 1998, and it only partially substitutes it with different typologies of permits (special protection/protezione speciale and special cases/casi speciali).

${ }^{8}$ The high number of arrivals as asylum seekers during the refugee crisis is also due to the closure of nearly all legal entry channels in Italy for economic migrants along with the 2008 economic crisis and the consequent severe reduction of numbers of the new working immigrants allowed to access the country through the annual decrees on flows/decreti flussi: about 31,000, most of them seasonal workers. Therefore, for many people "asylum seeking" channel is the only possible strategy. However, a sharp distinction between asylum seekers and economic migrants has been questioning (Crawley and Skleparis 2018).
} 
municipalities hosted a SPRAR project (35,650 migrants were hosted in SPRARs out of approximately 150,000 migrants hosted in the institutional reception structures). Therefore, the majority of migrants (approximately 80\%) are assisted through the CAS (Centres of Extraordinary Reception) system, which gives no clear role or corresponding responsibility to municipalities (Marchetti 2014). As mentioned in the previous section, CAS centres are instituted and controlled directly by the government (embodied by the Prefect), which at any time can decide to open a new centre in an area: the agreement of the corresponding municipality is not required.

Municipalities in Southern regions (especially Sicily, Apulia, Calabria and Campania) have been among the most willing in joining the SPRAR's network (see Table 1). In many cases policymakers acknowledged in these projects an opportunity for local economy, particularly in small municipalities in remote areas where the risk of depopulation is high. Another recognizable pattern in hosting SPRARs project concerns political subcultures: municipalities located in the traditional "red" regions (i.e. Emilia-Romagna and Tuscany) host much more SPRARs than municipalities in Northern regions with a traditional "white" sub-culture (that now has been translated in right-wing and antiimmigrant parties) like Veneto.

To be highlighted is that SPRAR's projects more explicitly than CASs are designed to promote refugee integration and, possibly, autonomy: to this end, each person enjoys a personal project where the beneficiary's specific experiences and abilities should be carefully taken into account by a multidisciplinary team. In other words, the SPRAR system explicitly aims at going beyond mere assistance, i.e. the furnishing of "bath, bed and bread".

Table 1 Migrants hosted in SPRARs in each Italian region, updated on 19 January 2019

\begin{tabular}{ll}
\hline REGION & Hosted migrants \\
\hline ABRUZZO & 746 \\
BASILICATA & 660 \\
CALABRIA & 3,537 \\
CAMPANIA & 2,883 \\
EMILIA ROMAGNA & 3,038 \\
FRIULI VENEZIA GIULIA & 429 \\
LAZIO & 4,467 \\
LIGURIA & 1,021 \\
LOMBARDIA & 2,422 \\
MARCHE & 1,325 \\
MOLISE & 1,028 \\
PIEMONTE & 1,986 \\
PUGLIA & 3,445 \\
TOSCANA & 1,837 \\
TRENTINO ALTO ADIGE & 392 \\
UMBRIA & 469 \\
VALLE D'AOSTA & 25 \\
VENETO & 784 \\
TOTAL & 35,650 \\
\hline SOUIE: SPRAR SYSten For PrOteCIOn & \\
\hline
\end{tabular}

Source: SPRAR, System for Protection of Asylum Seekers and Refugees (https://www.sprar.it/i-numeri-dello-sprar) 
Indeed, many local governments, after having declined the invitation to manage a SPRAR project, have protested against the settlement of refugees in their areas through CAS centres ${ }^{9}$. An exclusionary frame has emerged at the local level, since mayors and municipalities have resisted the imposition of refugees by national powers upon local communities (Marchetti and Mannocchi 2016).

Considering this process through the lens of policy analysis evidences that after a long time of non-decisions, a focusing event (i.e. the so-called 'refugee crisis') moved the government out of its emergency routines in coping with asylum seekers' reception and added a new item to the agenda for action (Peters 2015). According to Kingdon's seminal work on agendas (1985), focusing events provide opportunities to policy action. To put it another way, focusing events (sometimes) manage to move an issue on to an active policy agenda. The Agreement signed in 2014 within the State/regions conference and legislative decree no.142/2015 were some of the products of this focusing event. They actually gave a boost to policymakers to reframe the refugee issue at the national level: from an emergency to be coped with using ad hoc interventions to a phenomenon that needs to be managed using a longer-term perspective. In 2014, for instance, the government decided to increase significantly the funding to launch SPRAR projects (although the number of places in SPRAR was still largely insufficient).

If we make a screenshot of the immediate output of this focusing event, the relationship between tiers could be defined as somewhat in-between Scholten's pattern (2013) of "centralist" and "multilevel governance/cooperative": the agreement signed in 2014 and the decree approved in 2015 mark a stronger role of the national level in taking the initiative and designing rules and procedures to be followed for policy implementation. In this regard, it reminds to a top-down (centralist) relationship between the levels of governments. At the same time, a shared framing of the problem and response could be envisaged since local authorities, Regions and Government signed an agreement: it seemed likely that they could achieve coordination and cooperative working relationships. A departure from a "pure" centralist pattern towards a more multi-level governance one can be also observed if we consider that the participation of Local Authorities in SPRAR projects is not mandatory, leaving them the choice to commit or otherwise to this form of reception.

The implementation phase, nevertheless, strongly changes the scenario in the vertical multilevel patterns: conflicting frames emerge between tiers and, consequently, the cooperation is far from being obvious. This pattern represents a new wave of local policies of exclusion (Ambrosini 2018), which displays some differences in comparison with the past. In particular, it involves many regions and municipalities, and not only northern regions of Italy, where the anti-immigrant party Northern League has its strongholds. More than in the past, also municipalities ruled by centre-left coalitions are involved. From a theoretical point of view, this dynamic significantly differs from Scholten's decoupling pattern, which is characterized by the absence of any meaningful policy interaction and/or coordination between levels and that actually took place also

${ }^{9}$ Even if CASs host $80 \%$ of asylum-seekers, just 3 out 5 municipalities host refugees (https://www.lastampa. it/2018/02/08/italia/pi-strutture-per-i-profughi-in-un-anno-comuni-aprono-allaccoglienza-2j7bM70T6S2 zxdq8s95PHN/pagina.html): it happened in fact that CASs are often hosted in hotels, barracks or anyway big buildings where often lot of people (in some cases more than thousand) are hosted together, in some cases far from the town centre. 
in Italy as for (regular) migrant integration. The point here is much more related to conflicting and competing frames between different tiers due to political and institutional factors (see Spencer 2018) than to an absence of coordination. Indeed, the local level (in some cases even the regional level, e.g. Lombardy) ${ }^{10}$ openly defies the national governments: it is not the case that the State designs a policy and sub-state units do something different (as in decoupling patterns); rather, sub-state units (in particular local authorities) resist the State. Such resistance took two major directions: on the one hand, the majority of municipalities did not candidate for managing a SPRAR project on their territory; on the other hand, many municipalities protested against the establishment of a CAS on their territories. This second direction in some cases was successful, inhibiting the opening of CAS centres, in many other cases -even when not successful- achieved however a result: to highlight that local authorities were not responsible for the settlement of asylum seekers on the territory and were not available to cooperate in their social integration.

\section{Horizontal dynamics between state and non-state actors at the local level: exclusionary policies vs. practices of solidarity Mapping the players}

In this section, we move on the local level, where another significant piece of the fighting takes place. As we mentioned in the Introduction, the migration policy process is also the outcome of a game where many players other than public powers are involved. Non-state actors can be divided into two main heterogeneous groups: on the one hand, pro-migrant actors who challenge policies of exclusion; on the other hand, antiimmigrant actors who try to hamper asylum-seekers' reception.

As regards the former, four main categories can be distinguished (see Table 2, which draws on Fontanari and Ambrosini 2018; see also Garkisch et al. 2017 for a comprehensive review of Third Sector Organizations and migration). First, NGOs, or Third Sector Organizations (TSOs), which provide services to migrants and asylum seekers mainly in professional ways, and often in agreement with public bodies. This is the case of SPRARs and CASs, which are normally managed by NGOs receiving government funds. However, in other cases, as in the recent dispute on NGOs saving lives in the Mediterranean Sea (Irrera 2016), they can act with some independence from public policies, and even against the will of governments.

Second, other organised actors, including trade unions, churches and associations, which often combine practical support with political and cultural pressure. They employ professionals but also volunteers, can cooperate with public powers but also act beyond the laws, for instance providing help to people with a dubious or irregular legal status (Ambrosini and Van der Leun 2015; for a comparison with the USA: Hagan 2008)

Third, social movements, which place the defence of immigrant rights alongside other battles against the state and the capitalist system, but now increasingly provide also concrete services to migrants and asylum seekers: what Zamponi (2017) calls "direct social action".

\footnotetext{
${ }^{10} \mathrm{http} / / /$ www.repubblica.it/politica/2015/06/09/news/migranti_maroni_a_prefetti_stop_assegnazioni_-11643 9225/
} 
Table 2 Typology of supporters for asylum seekers and migrants with irregular status

\begin{tabular}{|c|c|c|c|c|}
\hline & $\begin{array}{l}\text { NGOs and } \\
\text { specialized } \\
\text { organizations }\end{array}$ & $\begin{array}{l}\text { Other CSOs } \\
\text { (associations of } \\
\text { volunteers, churches, } \\
\text { trade unions...) }\end{array}$ & Social movements & Common Citizens \\
\hline $\begin{array}{l}\text { Main } \\
\text { activities }\end{array}$ & $\begin{array}{l}\text { SAR in the sea, } \\
\text { reception on land }\end{array}$ & $\begin{array}{l}\text { Language schools; } \\
\text { Medical services; } \\
\text { Legal advocacy; } \\
\text { Bureaucratic } \\
\text { assistance; } \\
\text { Provision of basic } \\
\text { assistance: bath, bed } \\
\text { and bread }\end{array}$ & $\begin{array}{l}\text { Political protest, but } \\
\text { increasingly provision of } \\
\text { services (e.g. accommodation } \\
\text { in squatted buildings) }\end{array}$ & $\begin{array}{l}\text { Donation of } \\
\text { food, clothes, } \\
\text { money; } \\
\text { accommodation; } \\
\text { Volunteering; } \\
\text { socialization, } \\
\text { leisure }\end{array}$ \\
\hline $\begin{array}{l}\text { Political } \\
\text { engagement }\end{array}$ & $\begin{array}{l}\text { Variable, recently } \\
\text { higher against } \\
\text { harsher closure of } \\
\text { borders }\end{array}$ & $\begin{array}{l}\text { Variable, but } \\
\text { increasingly coupled } \\
\text { with the provision of } \\
\text { services }\end{array}$ & $\begin{array}{l}\text { Main focus (no } \\
\text { borders movements) }\end{array}$ & $\begin{array}{l}\text { Variable, often } \\
\text { relevant as the } \\
\text { reason to } \\
\text { mobilise }\end{array}$ \\
\hline Formalization & $\begin{array}{l}\text { High (formal } \\
\text { organizations, } \\
\text { contracts with } \\
\text { public authorities) }\end{array}$ & $\begin{array}{l}\text { Mix of formal } \\
\text { structures and } \\
\text { informal activities }\end{array}$ & Low, but self-organization & $\begin{array}{l}\text { Low } \\
\text { (spontaneous } \\
\text { mobilization) }\end{array}$ \\
\hline $\begin{array}{l}\text { Human } \\
\text { resources }\end{array}$ & $\begin{array}{l}\text { Mainly } \\
\text { professionals, } \\
\text { volunteers as } \\
\text { supplementary } \\
\text { resources }\end{array}$ & $\begin{array}{l}\text { Variable, but often } \\
\text { volunteering is } \\
\text { relevant }\end{array}$ & Militants/volunteers & Only volunteers \\
\hline
\end{tabular}

Fourth, support groups that spontaneously coalesce, especially around refugees settled in particular localities (Ellermann 2006; Fontanari 2017), for instance providing help for people in transit at the railway station of Milan (Sinatti 2019), or in the border zone of Ventimiglia-Val Roja (Giliberti and Queirolo Palmas 2020) ; or organizing sport and leisure activities at reception centres. In this category we place also individuals who offer specific assistance with food, money and accommodation (Fontanari and Ambrosini 2018), or language lessons, integrating those provided by law in reception centres.

The rationale of this classification lies in the degree of organization: NGOs are the most formal and organized actors, endowed with a professional staff. The second group includes various types of organizations, with different level of structuration, which provide services to asylum seekers and other migrants. The third group, social movements, by definition does not employ a professional staff: social movement depend on militants and cannot be confused with NGOs. Finally, spontaneous groups are the most informal actors.

For what concerns the beneficiaries, our attention focuses on asylum seekers and refugees. However, for various reasons this group cannot be easily distinguished from migrants without a legal status or in a dubious legal condition: there are for instance rejected asylum seekers, others who were rejected at the first evaluation, but are appealing against the decision, people who left reception centres or were expelled from them. With the exception of NGOs receiving public funds, the other actors normally do not discriminate between asylum seekers and other migrants.

As regards the forms of activities that such actors develop, there are essentially three types, the first being navigating the asylum system. At the political level, trade unions, religious institutions and voluntary associations, simultaneously demand more acceptance and support for asylum seekers, as well as more commitment in rescuing them in 
the sea. At the personal level, often through lawyers working for free, many of them help people in presenting their applications for asylum or in appealing against a refusal.

A second type of activity is the provision of services, particularly educational and social welfare services such as language courses, basic health services, clothing, food, and shelters for homeless; a condition in which many rejected asylum seekers, but also recognized refugees, actually fall. These services may be offered by volunteers and are often funded by private donations along with support from other social institutions. Overall, these activities provide what Leerkes (2016) calls "secondary poor relief" and Belloni (2016) describes more positively as "welfare from below". Another type of service is the delivery of moral support furnished by some civil society actors, particularly faith groups (Bloch et al. 2014: 110; Oliver et al. 2019). Third, there are activities associated with advocacy: political and cultural opposition to the criminalization of asylum seekers, protest activities against government policies of exclusion, support for the free movement of asylum seekers, and the promotion of views alternative to dominant representations of the issue (Ambrosini 2018).

The typology set out in Table 2 also describes for each category of supporters the level of political engagement, the degree of formalization of the various actors and the kind of human resources committed (if professional or voluntary).

As regards the second group, i.e. the anti-immigrant actors, it is embodied especially by the far-right protest related to the refugee crisis. Castelli Gattinara (2017) argues that the refugee crisis increased the amount of anti-immigrant demonstrations and farright street politics, although "hardly any research has investigated the predominant themes and narrative of anti-refugee and asylum campaigns" (p. 76). He also describes a variety of different forms taken by the anti-refugee mobilization in Italy, ranging from direct confrontational actions challenging the opening of refugee centers to institutional activities by established representative political organizations. Besides the mainstream narrative on the "invasion", other themes have been used in the anti-refugee discourse, such as the corruption of the political system (particularly targeting left-wing refugee aid organizations) and the discouragement of ordinary citizens that feel abandoned (p. 91), while the activists have strategically distanced themselves from the traditional far right, particularly as regards the language of racial superiority.

Even more important is the fact that many elected local authorities, not only those belonging to the anti-immigrant (Northern) League or the political right, have openly opposed the establishment of reception centers in their areas. Sometimes they have joined the far-right demonstrations; more often, they have autonomously enacted various forms of opposition, through declarations, administrative procedures, but also mobilizations of citizens and even road blocks. Various arguments have been used to justify such positions. Among the most recurrent is a frame of contrast between overbearing central powers and peaceful local communities, which are obliged to host unknown and dangerous aliens. Connected to this is the victim complex: local communities are the "victims" of an "invasion". This frame permits the political construction of an opposition between "us", the peaceful and integrated local community, and "them", the aliens, who are the bearers of danger, insecurity and the depletion of welfare resources. Furthermore, this view promotes the idea that "we" are under attack and have the right to defend ourselves, our families, our homes and our properties. In this framework, the local territory is conceived as a private property, or an extension of 
home. A famous slogan of the (Northern) League against immigrants declares "Masters in our own home" (Ambrosini 2018).

Following Faist (2002), this could be seen as an example of "symbolic politics" or "meta-politics", in which "real world issues" are connected with "fears around international migration" (Faist 2002, pp. 11-12). More specifically, "through meta-politics, low-level threats usually gain out-of-proportion significance". An important aspect is that by establishing a firm dichotomy between "us" and "them", local authorities and their supporters in some way recreate a meaning of community, reinforcing the bonds among local residents who feel that they share a common threat.

\section{Innovative approaches to bridging the gap of integration policies: strengths and weaknesses}

A crucial aspect of refugee policy in Italy is the lack of vision (and actions) as regards refugee integration once the timing for the institutional aid ends ${ }^{11}$. The issue of integration has been a weakness even for regular migration since the 1990s: the absence of a clear national direction and the high degree of devolution of competence on immigrant integration - and social policy more generally - to regional and local authorities have contributed to creating a context of limited and fragmented social protection (Campomori and Caponio 2013).

In order to cope with the deficiencies of public policies in this specific phase of transition from reception to integration, a number of actors - religious institutions, voluntary associations and also some municipalities hosting a SPRAR project - have launched innovative initiatives. Among them, the schemes for domestic hospitality of refugees in Italian families and the project of humanitarian corridors are particularly interesting and innovative. As regards domestic hospitality, it was experienced for the first time in 2008 in Turin within the SPRAR project and since 2015 it has been implemented in other cities, especially in the North and Center of Italy (for a detailed and up-to-date overview of these initiatives see Campomori and Feraco 2018; Marchetti 2018). These schemes display differences in their actual implementation, as regards the economic contribution which the families receive or the length of the project, but a common denominator is apparent: on the one hand, the belief that a (temporary) stay of refugees in a family -including the possibility of sharing the family's relational resources - could enable the building of networks useful for both labor market and social integration; on the other hand, these projects gamble on the idea that the example given by the hosting families could contribute to reducing people's prejudices and fear related to immigration and refugees and in generating trust. While positive feedbacks have emerged in relation to the integration objectives (Marchetti 2018) the number of refugees hosted in these projects is still low (Caritas Italiana has the primacy with 118 refugees hosted in various Italian cities). The political climate in Italy and the new

\footnotetext{
${ }^{11}$ A National Plan for the integration of people receiving international protection (Piano nazionale di integrazione dei titolari di protezione internazionale) was published on 26 September 2017 by the Ministry of the Interior, but it was still not comprehensive and it did not include migrants entitled to the former (before the law 132/2018) humanitarian protection (25\% of the overall number of asylum-seekers and $60 \%$ of migrants who receive a positive decision about their application).
} 
official discourse by national authorities in the period 2018-2019 hindered the diffusion of such project. On the other side, however (on 2 March 2019) a big demonstration in Milan, with probably more than 200,000 people in the streets, showed that a vocal minority had started to protest in favor of human rights and against the policies of closure enacted by the (Northern) League and 5Star Movement government (May 2018-August 2019).

Another weakness is the relation between public and private actors: in the case of Caritas Italiana (and partly of an association called Refugees Welcome) no official relations are envisaged, while in others the project is officially part of a SPRAR or CAS ${ }^{12}$, and third-sector associations manage the project on behalf of the municipality (in the case of SPRAR) or government (in the case of CAS). The schemes of domestic hospitality included in SPRAR or CAS do not have a national framework and regulation, but are local and therefore dependent on the voluntarism of single municipalities or prefectures, in addition to the commitment of non-public actors.

The second relevant practice - humanitarian corridors - aims at innovating both asylum policies and asylum seekers integration. Human corridors organize the arrival of people in need of humanitarian protection from the regions of immediate reception at the borders of war zones. They have similarities with resettlement policies supported by private sponsors in other countries (e.g., Canada) (Kumin 2015). Asylum seekers receive a permit and they can reach a safe country through regular flights, without dangerous journeys and profits for human smugglers. In Italy humanitarian corridors started at the end of 2015 after the signing of an agreement among the catholic S. Egidio community, the evangelical churches federation, the Waldensian Board and the Italian government. Around 1000 persons arrived safely in Italy through these corridors from Lebanon. In 2017 another corridor opened from Ethiopia, promoted by the Catholic Church (Caritas, Fondazione Migrantes and S.Egidio community), and 300 persons legally entered Italy. Other people arrived in 2018 from Lebanon and Ethiopia, summing up to almost 2,500 refugees received through the humanitarian corridors. After their arrival asylum seekers are hosted in parishes, religious institutes or apartments in various towns and regions, according to the idea of a "scattered reception". They follow a 12month integration process entirely funded by the private actors who promoted the project also with the support of volunteers. In the corridor from Ethiopia, every asylum seeker or family is accompanied by a "tutor-family" in acquiring knowledge of the local society, accessing services, attending Italian language courses, building social networks, looking for employment. This is a clear example of the activism of civil society in accordance with the State, and in particular of interreligious cooperation in this field (for other examples in Europe: Lyck-Bowen and Owen 2019). France, Belgium and Andorra followed the example and signed similar agreements with religious actors, showing the potential of the project of becoming a "good practice" internationally recognized.

Notwithstanding the strong innovative potential for asylum policies, also for humanitarian corridors some critical issues emerge, such as the actual time required for

\footnotetext{
${ }^{12}$ In the case of CAS the beneficiaries are not people with a recognized entitlement to international protection, but asylum seekers.
} 
integration (12 months may not be enough for every person) ${ }^{13}$ and the difficult balance between the need to support these persons and the need to foster their autonomy. Moreover, the selection of beneficiaries is a process that raises many dilemmas related, for instance, to the categories of people who should be given priority: the most vulnerable or persons with a better integration potential in the labor market.

The interplay between public powers and civil society: a typology

Local policies of exclusion, observed for either regular and irregular immigration (Ambrosini 2013), have been activated also in refugee reception. As we have already observed, in the first reception phase these policies translate into the attempt of many municipalities (and anti-immigrant activists) to avoid the settlement of refugees in their areas, loudly protesting against their arrival. In a second phase, when asylum seekers and refugees have actually settled, exclusionary policies manifested anytime local authorities denied refugees the residence card (certificato di residenza) or anytime municipalities hamper the possibility of receiving it, although in Italy migrants who obtain international or humanitarian protection are entitled to welfare provisions on the same conditions as Italian citizens (art.27 Legislative decree n.251/07) (Bolzoni et al. 2016; Gargiulo 2017).

Third-sector organizations, NGOs and religious institutions have counteracted these anti-immigrant practices either by providing basic services or fostering refugees' capacities, or giving them voice through public advocacy (Garkisch et al. 2017), or launching innovative practices for enhancing integration such as domestic hospitality.

In fact, the interplay between public powers and civil society organizations is not clear-cut, and it can assume different forms depending on the values and mission of the various civil society organizations and on the actions implemented by local authorities addressing asylum seekers' reception. To date, scholarly debate has not shed enough light on the relationship between state and non-state actors at the local level. In an attempt to bridge this gap we drew on some research studies (Ambrosini and Van der Leun 2015; Spencer 2018; Garkisch et al. 2017) and on a press review of online Italian newspapers (local news), identifying four different configurations of state and non-state actors' relations (see Table 3): a) closure vs. civil society activism; b) tolerance; c) institutional activism vs. anti-immigrant mobilizations; d) cooperation.

When closure prevails, an escalation occurs in the policy of exclusion implemented by local authorities, which are also hostile to private solidarity and hamper its action. Closure dynamics have happened for instance in some cities on Italy's borders, such as Ventimiglia: in August 2016 the left-wing mayor of that city issued a decree which made it illegal to give food and drink to asylum-seekers in public areas (8 months later the mayor canceled the decree) ${ }^{14}$. Other examples of closure are the cases of Udine (Friuli Venezia Giulia) and Saronno (Lombardy). As regards Udine, in June 2016 seven volunteers of the Ospiti in arrivo association were investigated because they had helped refugees with food, blankets and information on where they could find shelter in the city ${ }^{15}$. In the case of Saronno, in October 2016 the (Northern) League mayor

\footnotetext{
${ }^{13}$ As a matter of fact, the local branches of the humanitarian corridors are actually giving support to refugees hosted also beyond the 12 months' deadline.

${ }^{14}$ https://www.ilfattoquotidiano.it/2017/04/23/ventimiglia-vietato-dare-cibo-e-acqua-ai-migranti-solo-lamobilitazione-costringe-il-sindaco-pd-a-revocare-lordinanza/3538898/
} 
Table 3 Typology of the different relations between state and non-State actors at the local level

\begin{tabular}{|c|c|c|c|c|}
\hline & $\begin{array}{l}\text { Closure vs. civil s } \\
\text { ociety activism }\end{array}$ & Tolerance & $\begin{array}{l}\text { Institutional activism } \\
\text { vs. anti-refugees } \\
\text { mobilizations }\end{array}$ & Cooperation \\
\hline Dynamics & $\begin{array}{l}\text { Local authorities try } \\
\text { to prevent non-State } \\
\text { actors from helping } \\
\text { refugees }\end{array}$ & $\begin{array}{l}\text { Local authorities do } \\
\text { not hamper non-State } \\
\text { actors' activism }\end{array}$ & $\begin{array}{l}\text { Groups of residents } \\
\text { loudly protest against } \\
\text { institutional pro-asylum } \\
\text { seekers initiatives }\end{array}$ & $\begin{array}{l}\text { Local authorities and } \\
\text { non-State actors } \\
\text { cooperate in fostering } \\
\text { asylum-seeker reception }\end{array}$ \\
\hline $\begin{array}{l}\text { Some } \\
\text { empirical } \\
\text { evidence (Italy) }\end{array}$ & $\begin{array}{l}\text { Ventimiglia, } \\
\text { Saronno, Udine }\end{array}$ & $\begin{array}{l}\text { Centro Astalli (Roma, } \\
\text { Palermo, Catania, } \\
\text { Trento); NGOs' } \\
\text { clinics in Lombardy; } \\
\text { network Scuole senza } \\
\text { permesso. }\end{array}$ & $\begin{array}{l}\text { Castrovillari, San Giorgio } \\
\text { Ionico, Brindisi, Gorino }\end{array}$ & $\begin{array}{l}\text { SPRAR system } \\
\text { implementation in } \\
\text { Tuscany and } \\
\text { Emilia-Romagna }\end{array}$ \\
\hline
\end{tabular}

successfully opposed the opening of a reception center which should have been managed by the local Caritas (the center was already fully equipped for reception) ${ }^{16}$. Antirefugees movements and more or less numerous groups of local residents also supported closure of reception centers.

The configuration that we call tolerance emerges when the local authority implements exclusion policies, but at the same time silently accepts provisions delivered by NGOs. This is also the case of municipalities where the services implemented by public actors are largely insufficient and local authorities implicitly delegate them to civil society. This dynamic has had a long tradition in Italian integration policies since even before the refugee crisis (Caponio 2006; Campomori 2008). Some examples follow. In Milan the network Scuole senza permesso ${ }^{17}$ (Schools without permit) offers free Italian lessons to all migrants explicitly claiming that the stay permit is not required. In Rome, Trento, Palermo and Catania, Centro Astalli (part of the Jesuit Refugee Service in Italy) offers refugees medicines, professional medical help, meals, clothes: local authorities generally acknowledge Centro Astalli as a resource for the territory. In Lombardy (Northern Italy), many clinics managed by NGOs and employing hundreds of medical doctors as volunteers take care of health issues of irregular immigrants with the silent tolerance of public authorities (Ambrosini 2015; Piccoli 2016). Finally, Caritas offers many services including domestic hospitality with the project Protetto, Rifugiato a casa mia ${ }^{18}$. Sometimes, examples of closure dynamics change to tolerance, as happened in Ventimiglia, where the mayor canceled the decree which made illegal many forms of practical support.

We call institutional activism vs. anti-immigrant mobilization a dynamic where public powers display a quite welcoming approach toward refugees (for instance they open a SPRAR project in their area) but anti-refugee groups protest and fight. Empirically, this configuration and the last one (cooperation) tend to overlap, since when a SPRAR opens it is often the case that some people/organizations praise the initiative and even collaborate, while others combat it and protest.

\footnotetext{
$\overline{{ }^{15} \text { http://www.udinetoday.it/cronaca/archiviata-inchiesta-ospiti-arrivo-udine.html }}$

${ }^{16}$ https://www.ilfattoquotidiano.it/2016/10/01/migranti-sindaco-leghista-blocca-il-centro-accoglienza-delle-

suore-ma-non-ha-fatto-i-conti-con-il-viminale/3067047

${ }^{17} \mathrm{http}: / /$ www.scuolesenzapermesso.org/

${ }^{18}$ http://inmigration.caritas.it/
} 
An example of this dynamic is the case of Castrovillari ${ }^{19}$, a town in Calabria, where the decision to open a SPRAR for 20 asylum seekers triggered strong protests by rightwing party activists. Many other examples can be found in other municipalities, such as San Giorgio Ionico (Taranto) ${ }^{20}$ and Brindisi ${ }^{21}$, both located in Puglia. In San Giorgio Ionico citizens presented a petition to stop the implementation of the SPRAR project decided by the municipality; and in Brindisi residents organized a committee which finally managed to stop the project of a reception centre in the neighborhood of Santa Chiara.

Even in the traditionally left-wing and usually pro-immigrant Emilia-Romagna, there occurred an episode of intolerance which received wide media coverage: in October 2016, a large number of the citizens of the small town of Gorino (Emilia-Romagna) loudly protested against the arrival of 12 asylum-seekers (women), with some children, decided by the Prefect. The protest was so vehement that the Prefect finally decided to change his plans. A common denominator in all these events is that the protesters always wanted to make clear that they were not racist: the issue in their opinion was that their municipality was not the right place to host asylum-seekers (but they also added that "we cannot accommodate the whole of Africa in Italy").

The last ideal-type exhibits a certain level of cooperation between public and private actors: they engage in an attempt at dialogue and collaboration (positive governance). This should be the very philosophy of the SPRAR system, which foresees an active role of the municipality and local associations. Many municipalities in Tuscany and EmiliaRomagna are cases in point. Among the best practices are those of Parma and Bologna, which have also implemented domestic hospitality within SPRAR projects.

\section{Conclusions}

This article has argued for the convenience of integrating the venue shopping and the MLG approaches with a new perspective in order to obtain a comprehensive understanding of the policies related to asylum seeker reception, particularly in the phase of implementation. While the venue shopping framework deals only with migration control, MLG is not completely satisfactory for the analysis of the relationship between state and non-state actors. In fact, while the MLG vertical approach has been widely theorised and reached a quite sophisticated level of operationalization (see Scholten 2013, but also Zapata-Barrero and Barker 2014 for a partially different categorization), patterns in the interaction between public powers and civil society have not received the same theoretical attention. This deficiency in the scholarly debate suggests that MLG is better equipped to analyse the interaction among public powers, i.e. intergovernmental relations (Caponio and Jones-Correa 2017). Moreover, the dynamic and conflictual aspects of both vertical and horizontal relations, the role of actors and of their networks, the capacity to go beyond a simple description of the playfield, require further attention (for a review of criticisms to MLG approach: Pettrachin 2020).

\footnotetext{
${ }_{19}^{19}$ https://lacnews24.it/cronaca/castrovillari-apre-sprar-migranti-protesta-fratelli-italia_28658/

${ }^{20} \mathrm{http}: / /$ www.norbaonline.it/ondemand-dettaglio.php?i=27086\#!/

${ }^{21}$ https://www.quotidianodipuglia.it/brindisi/si_al_progetto_sprar_ma_nel_quartiere_monta_la_protesta-245 0661.html, https://www.quotidianodipuglia.it/brindisi/brindisi_santa_chiara_no_immigrati_affitto-2458584. html
} 
The article has made an exploratory attempt to analyse current asylum seeker and refugee reception in Italy, paying attention to both vertical and horizontal dynamics. It discloses that putting too much emphasis on the "negotiated order" among involved actors neglects an in-depth investigation of conflicts, which however largely contribute to policy outcomes. As for intergovernmental relations the analysis of Italian case displayed fluctuating patterns: from ones in-between centralist and cooperative, as seems when looking at espoused national policies, to an open conflict which becomes fully clear in the implementation phase. As a matter of fact, many local authorities resisted against state decisions and to the Prefects that should make them operative: what happened therefore was different from an absence of any meaningful policy coordination between levels, i.e. the decoupling pattern in Scholten's typology.

As for the horizontal dimension, in reception and integration policies the relationship between state and non-state actors gains particular importance at the local level: a variety of players and values confront each other on the playing field and it becomes evident that policy outcomes are also the result of their interactions (or absence of interactions), which cannot be foreseen in advance. Moreover, we argue that in analysing MLG dynamics it should be necessary to take account not only of the proimmigration lobbies, but also of anti-immigration groups, which could influence the decisions and behaviours of local authorities. The well-known "policy gap hypotheses" between goals and outcomes (Cornelius et al. 2004; De Haas et al. 2018), applied mainly in the field of immigration control, could be used also to analyse asylum-seeker and refugee reception and integration. For this purpose, we believe that it is crucial to investigate not only the various levels of policymaking, but also the diverse actors and logics that prevail in it (see Lahav and Guiraudon 2006). In particular, in the analysis of the horizontal dimension the concept of 'battleground' contributes to overcoming the conceptualization of governance as negotiated order among public and non-public actors (Alcantara and Nelles 2014): NGOs and civil societies often oppose public actors (and their policy) in various ways instead of looking for a "negotiated order", or some kind of "co-production", as it is evident on investigating local policies of exclusion or the dispute on NGOs in the Mediterranean (Ambrosini 2018). The concept of battleground encompasses conflict and cooperation, convergence and divergence, the autonomy of civil society facing public policies, while "negotiated order" emphasizes the agreement or the convergence between the actors involved.

The typology introduced in section 4 reporting different configurations in the relation between public and private actors highlights the need to consider not only the "official" governance, but also the overall dynamics among all the actors. The analytical framework included in the concept of 'battleground' enables an in-depth analysis of frames and actions of the various players. It makes clear that the social conditions of asylum seekers (and migrants in dubious or irregular legal condition) are not the direct output of official migration policies nor of "official" governance relations between state and non-state actors: declared public policies do not always coincide with implemented policies since other actors enter the scene and can partially change the outcome.

Future research should devote more empirical investigation to the actual dynamics of closure, tolerance, institutional activism and cooperation: e.g., which factors support the establishment of a type of relation or another one? Which actors are more active in different contexts and settings of relation? Under which conditions does civil society 
more effectively mobilize, or anti-immigrant movements gain ground? A comparative perspective would also strengthen and verify the explanatory potential of our conceptual proposal.

\section{Abbreviations}

CAS: Centres of Extraordinary Reception; MLG: Multilevel-governance; SIPROIMI: System of Protection for holders of International protection and Unaccompanied Minors; SPRAR: System of Protection for Asylum Seekers and Refugees

\section{Acknowledgements}

Not applicable

\section{Co-authorship}

The authors declare that they shared equally in the development of this manuscript

\section{Authors' contributions}

All authors read and approved the final manuscript

\section{Funding}

Not applicable

\section{Availability of data and materials}

Data sharing is not applicable to this article as no datasets were generated or analysed during the current study.

\section{Competing interests}

The authors declare that they have no competing interests.

\section{Author details}

${ }^{1}$ University of Venice, Malcanton Marcorà Dorsoduro 3484/A 30123, Venezia, Italy. ${ }^{2}$ University of Milan, Via Conservatorio 7, 20122 Milano, Italy.

Received: 7 June 2019 Accepted: 25 March 2020

Published online: 26 June 2020

\section{References}

Alcantara, C., \& Nelles, J. (2014). Indigenous Peoples and the State in Settler Societies: Toward a More Robust Definition of Multilevel Governance. Publius: The Journal of Federalism, 44(1), 183-204.

Ambrosini, M. (2013). 'We are against a Multi-Ethnic Society': Policies of Exclusion at the Urban level in Italy. Ethnic and Racial Studies, 36(1), 136-155. https://doi.org/10.1080/01419870.2011.644312.

Ambrosini, M. (2015). NGOs and Health Services for Irregular Immigrants in Italy: When the Protection of Human Rights Challenges the Laws. Journal of Immigrant \& Refugee Studies, 13(2), 116-134. https://doi.org/10.1080/15562948.2015. 1017631 doi: 10.1080/01419870.2011.644312.

Ambrosini, M. (2018). Irregular immigration in Southern Europe. Actors, Dynamics and Governance. Cham: Palgrave Macmillan. Ambrosini, M., \& Van der Leun, J. (2015). Introduction to the Special Issue: Implementing Human Rights: Civil Society and Migration Policies. Journal of Immigrant \& Refugee Studies, 13(2), 103-115. https://doi.org/10.1080/15562948.2015.1017632.

Bache, I., \& Flinders, M. (2004). Multi-Level Governance. Oxford: Oxford University Press.

Belloni, M. (2016). Learning How to Squat: Cooperation and Conflict between Refugees and Natives in Rome. Journal of Refugee Studies, 29(4), 506-527. https://doi.org/10.1093/jrs/few033.

Bloch, A., Sigona, N., \& Zetter, R. (2014). Sans Papiers. The Social and Economic Lives of young undocumented Migrants. London: Pluto Press.

Bolzoni, M., Gargiulo, E., \& Manocchi, M. (2016). The social consequences of the denied access to housing for refugees in urban settings: the case of Turin, Italy. International Journal of Housing Policy, 15(4), 400-417. https://doi.org/10.1080/ 14616718.2015.1053337.

Campomori, F. (2008). Immigrazione e cittadinanza locale. La governance dell'integrazione in Italia [Immigration and local citizenship. Governance of integration in Italy]. Roma: Carocci.

Campomori, F., \& Caponio, T. (2013). Competing frames of immigrant integration in the EU: geography of social inclusion in Italian regions. Policy Studies, 34(2), 162-179. https://doi.org/10.1080/01442872.2013.767586.

Campomori, F., \& Feraco, M. (2018). Integrare i rifugiati dopo i percorsi di accoglienza: tra le lacune della politica e l'emergere di (fragili) pratiche socialmente innovative [Integrating refugees after institutional reception: beteween politics' shortcomings and (fragile) social innovative practices]. Rivista Italiana di Politiche Pubbliche, 1(2018), 127-157. https://doi. org/10.1483/89478.

Caponio, T. (2006). Città italiane e immigrazione. Discorso pubblico e politiche a Milano, Bologna e Napoli [Italian cities and immigration. Public discourse and policies in Milan, Bologna and Naples]. Bologna: II Mulino.

Caponio, T., \& Borkert, M. (2010). The Local Dimension of Migration Policy-making. Amsterdam: Amsterdam University Press.

Caponio, T., \& Jones-Correa, M. (2017). Theorising migration policy in multilevel states: the multilevel governance perspective. Journal of Ethnic and Migration Studies. https://doi.org/10.1080/1369183X.2017.1341705.

Castelli Gattinara, P. (2017). Mobilizing against 'the invasion': Far right protest and the 'refugee crisis' in Italy. Mondi Migranti, 3, 75-95. https://doi.org/10.3280/MM2017-003004.

Cornelius, W., Martin, P. L., \& Hollifield, J. F. (2004). Controlling Immigration: A Global Perspective. Standford: Standford University Press. 
Crawley, H., \& Skleparis, D. (2018). Refugees, migrants, neither, both: categorical fetishism and the politics of bounding in Europe's 'migration crisis'. Journal of Ethnic and Migration Studies, 44(1), 48-64. https://doi.org/10.1080/1369183X.2017. 1348224.

da Cruz, N. F., Philipp, R. P., \& McQuarrie, M. (2019). New urban governance: A review of current themes and future priorities. Journal of Urban Affairs, 41(1), 1-19. https://doi.org/10.1080/07352166.2018.1499416.

Dabrowski, M., Bachtler, J., \& Bafoil, F. (2014). Challenges of Multi-Level Governance and Partnership: Drawing Lessons from European Union Cohesion Policy. European Urban and Regional Studies, 21(4), 355-363. https://doi.org/10.1177/ 0969776414533020.

De Haas, H., Natter, K., \& Vezzoli, S. (2018). Growing restrictiveness or changing selection? The nature and evolution of migration policies. International Migration Review, 52(2), 324-367. https://doi.org/10.1111/imre.12288.

Ellermann, A. (2006). Street-Level Democracy: How Immigration Bureaucrats Manage Public Opposition. West European Politics, 29(2), 293-309. https://doi.org/10.1080/01402380500512627.

Faist, T. (2002). "Extension du domaine de la lutte": international migration and security before and after September 11, 2001. International Migration Review, 36(1), 7-14. https://doi.org/10.1111/j.1747-7379.2002.tb00065.x.

Fontanari, E. (2017). Subjectivities in Transit. Fragmented Everyday Lives of Temporary Refugees (Im)mobile between European Borders. London: Routledge.

Fontanari, E., \& Ambrosini, M. (2018). Into the Interstices: Everyday Practices of Refugees and Their Supporters in Europe's Migration 'Crisis'. Sociology, 52(3), 587-603. https://doi.org/10.1177/0038038518759458.

Gargiulo, E. (2017). The limits of local citizenship: administrative borders within the Italian municipalities. Citizenship Studies, 21(3), 327-343. https://doi.org/10.1080/13621025.2016.1277982.

Garkisch, M., Heidingsfelder, J., \& Beckmann, M. (2017). Third Sector Organization and Migration: A Systematic Literature Review on the Contribution of Third Sector Organization in View of Flight, Migration and Refugee Crises. VOLUNTAS: International Journal of Voluntary and Nonprofit Organizations, 28(5), 1839-1880. https://doi.org/10.1007/s11266-017-9895-4.

Giliberti, L., \& Queirolo Palmas L. (2020). Solidarities in Transit on the French-Italian Border: Ethnographic Accounts from Ventimiglia and the Roya Valley. In M. Ambrosini, M. Cinalli, \& D. Jacobson (Eds.) Migration, Borders and Citizenship (pp. 109-140). Cham: Palgrave Macmillan.

Guiraudon, V. (2000). European Integration and Migration Policy: Vertical Policy-Making as Venue Shopping. Journal of Common Market Studies, 38(2), 251-271. https://doi.org/10.1111/1468-5965.00219.

Guiraudon, V., \& Lahav, G. (2000). The State Sovereignty Debate Revisited: The Case of Migration Control. Comparative Political Studies, 33(2), 163-195. https://doi.org/10.1177/0010414000033002001.

Hagan, J. (2008). Migration Miracle. Faith, Hope and Meaning on the Undocumented Journey. Cambridge: MA Harvard University Press.

Hepburn, E., \& Zapata-Barrero, R. (Eds.) (2014). The Politics of Immigration in Multilevel States. Governance and Political Parties. Houndmills: Palgrave Macmillan.

Irrera, D. (2016). Migrants, the EU and NGOs: The practice of non-governmental SAR operations. Romanian Journal of European Affairs, 16(3), 20-35.

Kingdon, J. W. (1985). Agendas, Alternatives and Public Policies. New York: Longman (reprinted in 2003).

Kumin, J. (2015). Welcoming Engagement: How Private Sponsorship Can Strengthen Refugee Resettlement in the European Union. Brussels: Migration Policy Institute Europe. http://www.migrationpolicy.org/research/welcomingengagementhow-privatesponsorship-can-strengthen-refugee-resettlement-european. Accessed 8 August 2019.

Lahav, G., \& Guiraudon, V. (2006). Actors and venues in immigration control: Closing the gap between political demands and policy outcomes. West European Politics, 29(2), 201-223. https://doi.org/10.1080/01402380500512551.

Leerkes, A. (2016). Back to the Poorhouse? Social Protection and Social Control of Unauthorised Immigrants in the Shadow of the Welfare State. Journal of European Social Policy, 26(2), 140-154. https://doi.org/10.1177/0958928716637139.

Lyck-Bowen, M., \& Owen, M. (2019). A multi-religious response to the migrant crisis in Europe: A preliminary examination of potential benefits of multi-religious cooperation on the integration of migrants. Journal of Ethnic and Migration Studies, 45(1), 21-41. https://doi.org/10.1080/1369183X.2018.1437344.

Marchetti, C. (2014). Refugees and Forced Migrants in Italy: The Pendulum between 'Emergency' and 'System'. REMHU: Revista Interdisciplinar da Mobilidade Humana, 22(43), 53-70. https://doi.org/10.1590/1980-85852503880004304.

Marchetti, C. (2018). L'accoglienza dei rifugiati in famiglia. Prove di comunità interculturali [The reception of refugees in the family. Evidence of intercultural communities]. In Fondazione Migrantes Rapporto Asilo 2018, (pp. 179-208).

Marchetti, C., \& Mannocchi, M. (2016). Introduzione. Rifugiati in transito attraverso l'Europa [Introduction. Refugees in transit through Europe]. Mondi Migranti, 10(1), 21-38. https://doi.org/10.3280/MM2016-001002.

Oliver C., Geuijen K., Dekker R. (2019) Plan Einstein: Utrecht's Urban Experiment on Asylum Seeker Reception - Executive summary of Independent Evaluation. https://www.compas.ox.ac.uk/2019/plan-einstein-utrechts-urban-experiment-onasylum-seeker-reception-executive-summary-of-independent-evaluation/

Panizzon, M., \& Van Riemsdijk, M. (2018). Introduction to Special Issue: 'Migration governance in an era of large movements: a multilevel approach'. Journal of Ethnic and Migration Studies, 45(8), 1225-1241. https://doi.org/10.1080/1369183X.2018.1441600.

Peters, B. G. (2015). Advanced Introduction to Public Policy. Northampton: Edward Elgar Publishing.

Pettrachin A. (2020). Understanding the 'Refugee Crisis': An Actor-Centred Analysis of the Constitution of Asylum Governance in Italy. [Unpublished Phd thesis]. University of Sheffield.

Piccoli L. (2016). Left out by the State, Taken in by the Region? Explaining the Regional Variation of Healthcare Rights for Undocumented Migrants in Italy, Spain, and Switzerland, NCCR on the Move (Working Paper Series \#10, University of Neuchatel). Retrieved from https://nccr-onthemove.ch/publications/left-out-by-the-state-taken-in-by-the-regionexplaining-the-regional-variation-of-healthcare-rights-for-undocumented-migrants-in-italy-spain-and-switzerland/.

Schmitter, P. (2004). Neo Functionalism. In A. Wiener, \& T. Diez (Eds.), European Integration Theory (pp. 45-74). Oxford: Oxford University Press.

Scholten, P. (2013). Agenda Dynamics and the Multi-Level Governance of Intractable Policy Controversies: the case of Integration Policies in the Netherlands. Policy Sciences, 46(3), 217-236. https://doi.org/10.1007/s11077-012-9170-x.

Scholten, P., Engbersen, G., van Ostaijen, M., \& Snel, E. (2018). Multilevel governance from below: how Dutch cities respond to intra-EU mobility. Journal of Ethnic and Migration Studies, 44(12), 2011-2033. https://doi.org/10.1080/1369183X.2017.1341707. 
Scholten, P., \& Pennix, R. (2016). The Multi-Level Governance of Migration and Integration. In B. Garcès-Mascarenas, \& R. Pennix (Eds.), Integration Processes and Policies in Europe- A Three Way Process? (pp. 91-108). New York: Springer.

Sinatti, G. (2019). Humanitarianism as politics: Civil support initiatives for migrants in Milan's hub. Social Inclusion, 7(2), 139-148. https://doi.org/10.17645/si.v7i2.1968.

Spencer, S. (2018). Multi-level governance of an intractable policy problem: migrants with irregular status in Europe. Journal of Ethnic and Migration Studies, 44(12), 2034-2052. https://doi.org/10.1080/1369183X.2017.1341708.

Taylor, A., Geddes, A. P., \& Lees, C. (2013). The European Union and South East Europe: The Dynamics of Europeanization and Multilevel Governance. London: Routledge.

Zamponi, L. (2017). Practices of Solidarity: Direct Social Action, Politicisation and Refugee Solidarity Activism in Italy. Mondi Migranti, 11(3), 97-117. https://doi.org/10.3280/MM2017-003005.

Zapata-Barrero, R., \& Barker, F. (2014). Multilevel Governance of Immigration in Multinational States. 'Who Governs' reconsidered. In E. Hepburne, \& B. R. Zapata (Eds.), The Politics of Immigration in Multilevel States, (pp. 19-40). Houndmills: Palgrave Macmillan.

Publisher's Note

Springer Nature remains neutral with regard to jurisdictional claims in published maps and institutional affiliations.

Submit your manuscript to a SpringerOpen ${ }^{0}$ journal and benefit from:

- Convenient online submission

- Rigorous peer review

- Open access: articles freely available online

High visibility within the field

- Retaining the copyright to your article

Submit your next manuscript at $\boldsymbol{\nabla}$ springeropen.com 